\title{
The potential of epigenetics in stress-enhanced fear learning models of PTSD
}

\author{
Ashley M. Blouin, ${ }^{1}$ Stephanie E. Sillivan, ${ }^{1}$ Nadine F. Joseph, and Courtney A. Miller \\ Department of Metabolism and Aging and Department of Neuroscience, The Scripps Research Institute, Jupiter, Florida 33458, USA
}

\begin{abstract}
Prolonged distress and dysregulated memory processes are the core features of post-traumatic stress disorder (PTSD) and represent the debilitating, persistent nature of the illness. However, the neurobiological mechanisms underlying the expression of these symptoms are challenging to study in human patients. Stress-enhanced fear learning (SEFL) paradigms, which encompass both stress and memory components in rodents, are emerging as valuable preclinical models of PTSD. Rodent models designed to study the long-term mechanisms of either stress or fear memory alone have identified a critical role for numerous epigenetic modifications to DNA and histone proteins. However, the epigenetic modifications underlying SEFL remain largely unknown. This review will provide a brief overview of the epigenetic modifications implicated in stress and fear memory independently, followed by a description of existing SEFL models and the few epigenetic mechanisms found to date to underlie SEFL. The results of the animal studies discussed here highlight neuroepigenetics as an essential area for future research in the context of PTSD through SEFL studies, because of its potential to identify novel candidates for neurotherapeutics targeting stress-induced pathogenic memories.
\end{abstract}

Post-traumatic stress disorder (PTSD) is triggered by experiencing or witnessing a traumatic event and is characterized by pathogenic memory (e.g., recurrent, involuntary memories that trigger intense stress), avoidance of reminders, hyperarousal and reactivity, negative mood, cognitive alterations, and a persistence of symptoms for at least $1 \mathrm{mo}$. Although only a fraction of people exposed to trauma develop PTSD, a history of stress exposure prior to witnessing a traumatic event increases the risk (Breslau et al. 2014). Therefore, some animal models of PTSD use multidimensional stress and fear memory paradigms to model the disorder. In stress-enhanced fear learning (SEFL), a rodent is exposed to a stressor or combination of stressors prior to undergoing classical fear conditioning. Models that utilize SEFL closely reproduce many core symptoms of PTSD, including enhanced fear learning, generalized anxiety, heightened startle, and impaired extinction. Furthermore, therapeutics that alleviate symptoms in some PTSD patients, such as selective serotonin reuptake inhibitors (SSRIs) and D-cycloserine (DCS) (Albucher and Liberzon 2002; de Kleine et al. 2015), also mitigate some of the effects produced by SEFL procedures in rodents (Takahashi et al. 2006; Yamamoto et al. 2008). Finally, animal studies have revealed the importance of several brain regions such as the amygdala, hippocampus, and medial prefrontal cortex (mPFC) in mediating the effects of SEFL (Maren and Holmes 2016), and these regions show abnormal activity in PTSD patients (Milad et al. 2009; Pitman et al. 2012; Stevens et al. 2014; Maren and Holmes 2016). Taken together, SEFL models have relatively high face, construct and predictive validity for PTSD and provide an exciting avenue for the investigation of neurobiological mechanisms, including neuroepigenetics, mediating the debilitating symptoms of this illness.

Epigenetic modifications alter the mRNA and protein expression of a given gene without changing the inherent DNA sequence, allowing cells to fine-tune expression patterns of the genome in a tissue-specific manner. Core histone proteins provide physical control over transcriptional events by winding DNA into

\footnotetext{
1These authors contributed equally to this work.

Corresponding author: cmiller@scripps.edu

Article is online at http://www.learnmem.org/cgi/doi/10.1101//m.040485. 115.
}

a compact, repressive state, or unwinding it into a relaxed, permissive state. Modifications to histone tails, such as acetylation, methylation, and phosphorylation, occur throughout the genome and interact with neighboring chromosomes when DNA is in a folded conformation to yield complex transcriptome patterns within a given cell (Zhou et al. 2011). DNA itself can also be directly modified through covalent modifications of the cytosine pyramidine ring. Addition of a methyl group is typically associated with transcriptional silencing, whereas the opposite is achieved through hydroxymethylation. DNA methylation, once thought to be an irreversible modification, has proven to be highly dynamic in the brain thanks to the process of hydroxymethylation (Miller and Sweatt 2007; Kim et al. 2009; Kriaucionis and Heintz 2009; Guo et al. 2011; Kaas et al. 2013; Li et al. 2013; Rudenko et al. 2013) and can interact with histone modifications to produce a complex transcriptional "code" for any given gene (Miller et al. 2008; Vaissiere et al. 2008). Because epigenetic adaptations have been shown to be induced by stress and also to support the learning and modulation of fear memories (see later sections), deciphering epigenetic mechanisms unique to their interaction in SEFL has significant implications for the treatment of PTSD.

\section{Stress-enhanced fear learning models}

Animal models of SEFL measure the effect of a stressor on subsequent fear memory (Fig. 1; Table 1). Fear conditioning is generally performed anywhere from $24 \mathrm{~h}$ to $10 \mathrm{~d}$ after the stressor and is most commonly a classical fear conditioning procedure involving the temporal pairing of a neutral conditioned stimulus (CS) with an aversive unconditioned stimulus (US). In cued fear conditioning, the CS is typically an auditory cue and in contextual fear conditioning, the CS is the context in which the rodent receives the

\footnotetext{
C 2016 Blouin et al. This article is distributed exclusively by Cold Spring Harbor Laboratory Press for the first 12 months after the full-issue publication date (see http://learnmem.cshlp.org/site/misc/terms.xhtml). After 12 months, it is available under a Creative Commons License (AttributionNonCommercial 4.0 International), as described at http://creativecommons. org/licenses/by-nc/4.0/.
} 


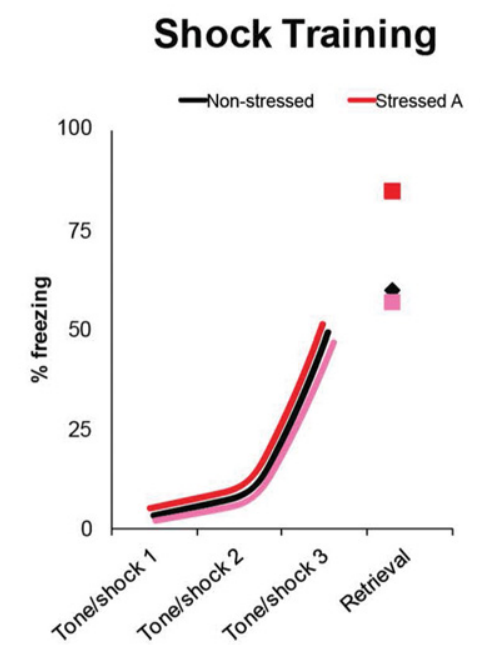

Extinction

Figure 1. SEFL outcomes after cued fear conditioning. Stress enhanced fear learning is performed by exposing animals to a stressor prior to fear conditioning. SEFL can induce alterations in fear memory expression, extinction, retention, or combinations of these three behaviors. In this example, stressed animals undergo cued fear conditioning that consists of three shocks, each paired with an auditory cue. Upon retrieval of the fear memory, stressed animals may have heightened fear expression (Stressed A). Depending on the SEFL model, a history of stress may not elevate fear expression (Stressed B), but instead affect the rate of fear extinction (Stressed C) or the retention of extinction between sessions (Stressed D).

shock, or US. The pairing of the CS and US leads to freezing, a defensive behavior characterized by the absence of all movement except for respiration, in response to later presentation of the CS alone. The strength of the fear memory can be measured by quantifying freezing to a brief CS exposure. Extinction is displayed as reduced freezing to the CS and occurs only after repeated, nonreinforced CS exposures. Extinction is not considered a reversal of the fear memory, but at least in part, the formation of a new memory that inhibits expression of the original, fearful conditioned response (Bouton 2002).

SEFL models utilize a variety of environmental, physical and psychological stressors, such as immobilization or restraint stress, swim stress, inescapable shock, elevated platform stress, early-life stress, social stress and exposure to predator odors. One of the most commonly used stressors is restraint stress, where an animal is immobilized by placement in a plastic restraint such as a Falcon tube or Decapicone bag or its limbs are secured to a wooden board. Evidence exists for effects of both a single restraint event and repeated restraints on subsequent fear learning. Several studies have shown increased freezing upon exposure to a context previously paired with shock in rodents that have undergone brief (30 min-2 h) restraint (Cordero et al. 2003; Rodriguez Manzanares et al. 2005; Tronson et al. 2010), whereas other studies utilizing repeated restraint have observed increased freezing upon exposure to a tone previously paired with shock (Meyer et al. 2014; Suvrathan et al. 2014; Baratta et al. 2015). The degree to which restraint stress affects fear learning, generalization, extinction rate, or extinction retention differs, depending on the method and duration of restraint, the varying delays between the stress and fear conditioning and differences in the amount of shock utilized during conditioning (Miracle et al. 2006; Andero et al. 2011, 2013; Chauveau et al. 2012). Although studies of the effectiveness of therapeutics have generally used SEFL models other than restraint, a recent study showed that 7,8-dihydroxyflavone (7,8-DHF), a TrkB agonist, was able to rescue impaired extinction following restraint stress (Andero et al. 2011). TrkB is a receptor for brain-derived neurotropic factor (BDNF), a regulator of neuronal plasticity that supports cognition and learning throughout life
(Bramham and Panja 2014; Karpova 2014; Lu et al. 2014) and can accelerate extinction in classical fear learning paradigms (Peters et al. 2010; Rosas-Vidal et al. 2014). The efficacy of this approach is likely to be tested in human studies because 7,8-DHF is safe and can cross the blood-brain barrier, and evidence supports the hypothesis that BDNF signaling is altered in PTSD patients (Dell'Osso et al. 2009; Hauck et al. 2010; Soliman et al. 2010).

One SEFL model known for its predictive and construct validity is the single-prolonged stress (SPS) model. This model involves the presentation of a complex stressor (restraint, $20 \mathrm{~min}$ forced swim and exposure to diethyl ether until consciousness is lost) prior to presentation of fear conditioning. This model has the advantage of representing the multidimensional nature of PTSD and results in enhanced fear conditioning and impaired extinction (Iwamoto et al. 2007; Kohda et al. 2007; Knox et al. 2012), as well as increased fear renewal (Yamamoto et al. 2009), exaggerated startle (Khan and Liberzon 2004), enhanced glucocorticoid negative feedback (Liberzon et al. 1997; Iwamoto et al. 2007), deficits in spatial memory, and stress-induced analgesia (Yamamoto et al. 2009). SSRIs can reverse the increase in contextual fear conditioning (Takahashi et al. 2006) and DCS (Yamamoto et al. 2008) ameliorates the impaired extinction in the SPS model, which gives the model good predictive validity, as these drugs alleviate symptoms in some PTSD patients (Albucher and Liberzon 2002; de Kleine et al. 2015). The SPS model produces enhanced contextual fear and is associated with hippocampal abnormalities, although not much is known about the involvement of the mPFC or amygdala in this model (Maren and Holmes 2016). The enhanced contextual fear memory in this model is consistent with the finding that some PTSD patients show increased sensitivity to contextual cues (Grillon 2002), and the impaired extinction and hippocampal abnormalities are consistent with the finding that PTSD patients have difficulty using context to regulate fear (Rougemont-Bucking et al. 2011; Garfinkel et al. 2014).

Another model of SEFL utilizes repeated footshock as a stressor and is similar to SPS in that it produces a very robust phenotype (Rau et al. 2005; Szczytkowski-Thomson et al. 2013). In this model, $>90 \%$ of outbred rats show a PTSD-like phenotype. When these same rats are given 15 shocks over a 90-min period, subsequent contextual and cued fear conditioning is enhanced, even $90 \mathrm{~d}$ following the 15-shock stressor. Reducing the stressor to four shocks instead of 15 results in only $20 \%$ of rats developing PTSD-like symptoms, which more closely resembles the human situation. Because repeated footshock enhances cued conditioning, in addition to contextual fear, the effects of this model are likely due to a sensitization of the fear circuitry and not merely generalization to a shock context (Rau et al. 2005). Consistent with this, the model reliably produces changes in the amygdala, a brain region with known pathology in PTSD patients (Maren and Holmes 2016; Perusini et al. 2016). This model is also able to produce a variety of PTSD symptoms, such as reduced exploration, depression, increased propensity to drink alcohol, enhanced reactivity to loud noise, anxiety and disrupted diurnal cycle of corticosterone (Perusini et al. 2016). Tailshock has also been 
Table 1. Current SEFL models, including the stress utilized and its effect on fear memory

\begin{tabular}{|c|c|c|c|}
\hline Species & Stressor & Fear measurement & Citation \\
\hline Mice & Restraint/immobilization & $\begin{array}{l}\text { Enhanced cued fear } \\
\text { Enhanced context fear } \\
\text { Impaired cued extinction }\end{array}$ & $\begin{array}{l}\text { Andero et al. (2013), Baratta et al. (2015), Meyer et al. (2014) } \\
\text { Tronson et al. (2010) } \\
\text { Andero et al. (2011), Chauveau et al. (2012) }\end{array}$ \\
\hline Rats & Restraint/immobilization & $\begin{array}{l}\text { Enhanced cued fear } \\
\text { Enhanced context fear } \\
\text { Impaired cued extinction }\end{array}$ & $\begin{array}{l}\text { Suvrathan et al. (2014) } \\
\text { Rodriguez Manzanares et al. (2005), Cordero et al. (2003) } \\
\text { Miracle et al. (2006) }\end{array}$ \\
\hline Rats & Single prolonged stress (SPS) & $\begin{array}{l}\text { Enhanced context fear } \\
\text { Impaired cued and context extinction }\end{array}$ & $\begin{array}{l}\text { Iwamoto et al. (2007), Kohda et al. (2007) } \\
\text { Knox et al. (2012) }\end{array}$ \\
\hline Rats & Shock & $\begin{array}{l}\text { Enhanced cued and context fear } \\
\text { Enhanced eyeblink conditioning } \\
\text { Increased avoidance }\end{array}$ & $\begin{array}{l}\text { Rau et al. (2005) } \\
\text { Shors et al. (1992) } \\
\text { Brennan et al. (2005) }\end{array}$ \\
\hline Rats & Predator odor & Increased avoidance & Brennan et al. (2006) \\
\hline Mice & Social stress & Enhanced cued fear & Dubreucq et al. (2012) \\
\hline Rats & Maternal separation & Enhanced context fear & Toda et al. (2014) \\
\hline Mice & Swim stress & Impaired cued extinction & Izquierdo et al. (2006) \\
\hline Rats & Elevated platform stress & Impaired cued and context extinction & Akirav and Maroun (2007) \\
\hline
\end{tabular}

successfully used to enhance fear learning. When tailshock precedes the pairing of a white noise with periorbital shock, eyeblink conditioning is enhanced (Shors et al. 1992). Furthermore, tailshock has been shown to increase avoidance responding, where rats press a lever to avoid receiving a footshock (Brennan et al. 2005). Measuring avoidance responding rather than freezing behavior in rodents is thought to model the active component of learned fear and represents a coping strategy. This behavior is excessive in PTSD, as patients actively avoid people or places that serve as reminders of the traumatic situation and may impede extinction learning.

Some stressors are used to model a psychological, rather than physical, form of stress. Exposure to trimethylthiazoline (TMT), a component of fox odor, is stressful to rats because the fox is a predator. This stressor is naturalistic and does not involve the presentation of painful stimuli, so it is thought to more closely model a psychological stressor. Avoidance responding has also been shown to increase following the presentation of predator stress (Brennan et al. 2006). Another naturalistic stressor used is social defeat, where a rodent (intruder) is placed into the cage of a larger, dominant (resident) rodent. Although this procedure involves fighting between the two rodents that can be painful, prolongation of the stressor is achieved by caging the intruder inside the resident's cage, where it is protected from physical harm but can still experience stress via visual and olfactory cues. This stress increases cued fear conditioning and anxiety-like behavior in the elevated plus maze (Dubreucq et al. 2012). A third psychological stressor is maternal separation, which more closely models the increased incidence of PTSD in individuals that have experienced childhood stress. This procedure, which involves separation of pups from the mother for a few hours each day in early postnatal life, enhances contextual fear memory in adulthood (Toda et al. 2014).

Models producing extinction deficits may be valuable for screening therapeutics, as studies demonstrate impaired fear extinction in PTSD patients (Blechert et al. 2007; Milad et al. 2009; Norrholm et al. 2011). Restraint, SPS, and shock have all been shown to affect both fear conditioning and extinction. Other stressors, such as swim stress, have been found to have no effect on fear memory, but to impair extinction memory (Izquierdo et al. 2006). Interestingly, stress after fear conditioning is also capable of altering fear memory. Indeed, the stress of 30 min spent on an elevated platform is sufficient to produce deficits in extinction when performed after contextual or cued fear conditioning (Akirav and Maroun 2007; Maroun et al. 2013), and these deficits are reversed by intra-amygdala DCS (Akirav et al. 2009).

\section{The neuroepigenetics of stress}

Stress elicits both immediate and long-lasting psychological, physical, and emotional strain on an individual, leading to profound neurobiological changes that impact future behavioral responses. Animal models of stress exposure have identified epigenetic modifications in key brain areas known to be critical components of the circuitry responsible for both the expression of anxiety and formation and expression of fear memories, such as the frontal cortex, hippocampus, and amygdala (Gudsnuk and Champagne 2012; Stankiewicz et al. 2013). Because a thorough review of the epigenetics of stress has been described elsewhere (Vialou et al. 2013), emphasis will be placed on the specific stressors utilized in SEFL models, as described in the preceding section.

Exposure to a natural predator or predator odor evokes epigenetic modifications of the $B d n f$ gene. In a complex psychosocial stress paradigm, rats subjected to a combination of restraint stress, live cat exposure, and social housing instability displayed hypermethylation of $B d n f$ exon IV in the dorsal hippocampus (dentate gyrus and CA1), but hypomethylation in the ventral hippocampus (CA3) (Roth et al. 2011). In a milder predator stress paradigm, a genome-wide methylation screen identified a number of differentially methylated regions in the rat hippocampus following exposure to soiled cat litter and highlighted the relevance of Dlgap2's methylation state to anxiogenic behaviors (ChertkowDeutsher et al. 2010). Dlgap2, a gene that encodes a postsynaptic density protein, was more likely to be unmethylated in animals that displayed an anxious phenotype in this predator stress paradigm. Because not all animals exposed to the cat litter developed the anxiety-like phenotype, hypermethylation of Dlgap2 and decreased mRNA expression of the gene are associated with resilience to stress. Predator stress also induces phenotypic variability in stress coping responses that can be linked to the degree of methylation of the hormone vasopressin $(A v p)$ in the amygdala (Bowen et al. 2014). The methylation status of $A v p$, a secreted neuropeptide that can modulate higher cognitive processes such as social behavior (Meyer-Lindenberg et al. 2011), segregates animals into resilient or susceptible phenotypes and is positively correlated with higher levels of corticosterone in the susceptible group. Such epigenetic regulation may be linked to intergroup variability observed in rodent stress paradigms and recapitulates the variability in human stress responses to seemingly equivalent traumatic events.

Decreases in global DNA methylation have been observed in the hippocampus, cortex, and periaqueductal gray of stressed 
animals (Rodrigues et al. 2015). Furthermore, in the hippocampus of stressed animals, the 3'-UTR of the glucocorticoid receptor gene $N r 3 c 1$ was hyper-hydroxymethylated, a modification associated with increased transcription (Li et al. 2015). These parallel studies also identified a pattern of hydroxymethylation throughout the genome in stressed animals, with many sites of differential hydroxymethylation located on known stress-related genes that were concomitantly changed at the mRNA level (Li et al. 2016). These large-scale data sets suggest that even brief stressors induce epigenetic patterns that are capable of changing the global transcriptional profile of the brain by creating an environment that is permissible for the up-regulation of stress response genes. Conversely, chronic restraint stress imposes inhibitory regulation of the glucocorticoid receptor, presumably through increased methylation of the promotor of the Npas4 regulatory transcription factor (Furukawa-Hibi et al. 2015). Dissociating the epigenetic effects of acute versus chronic stress will likely yield more information about the long-lasting effects of stress and how resilience can be encoded to cope with acute stressors.

Epigenetic regulation of $B d n f$ by histone modifications has been studied in animal models of restraint stress with conflicting results. Using a $2 \mathrm{~h}$ restraint stress paradigm, Fuchikami et al. reported lower histone $\mathrm{H} 3$ acetylation of $B d n f$ in the hippocampus, accompanied by corresponding decreases in $B d n f$ mRNA expression (Fuchikami et al. 2010). However, this effect was not reproduced in a more recent study (Ieraci et al. 2015). The latter study also examined the expression of the enzymes responsible for removing acetyl groups, histone deacetylases (HDACs). Levels of the specific HDAC isoforms 4, 5, 7, and 9 were measured at varying time points after stress, with dynamic regulation reported between 2 and $8 \mathrm{~h}$ after restraint stress. The mRNA expression of all isoforms returned to baseline at $24 \mathrm{~h}$ poststress, suggesting that restraint stress may only briefly regulate histone modifications in the hippocampus to allow for transcription of stressresponsive genes. Studies that have examined histone modifications in other brain regions after restraint stress support this notion; restraint stress has short-lived effects on global histone H3 phosphorylation in the nucleus accumbens and prelimbic cortex, with large increases in phosphorylation that return to baseline in a relatively quick manner (Rotllant et al. 2013). Predator stress also increases phosphorylation of histone $\mathrm{H} 3$ in adult dentate gyrus granule cells of the hippocampus (Bilang-Bleuel et al. 2005) and acetylation of histones $\mathrm{H} 3$ and $\mathrm{H} 4$ in the amygdala (Ragu Varman and Rajan 2015). Perhaps not surprisingly, differences in the duration and severity of the stressor induce differential patterns of lysine methylation on $\mathrm{H} 3$ in the CA1 and dentate gyrus regions of the hippocampus (Hunter et al. 2009). These findings are relevant for dissociating the molecular adaptations of chronic depressive states from acute, isolated traumatic exposures because the varying degrees of stress likely have different epigenetic signatures.

Along this same line, a recent study used a combination of stressors to demonstrate that lasting epigenetic changes arising from a chronic stress paradigm may be briefly disrupted with subsequent short-term stress exposures (Nasca et al. 2015). Chronic restraint stress decreased acetylation on lysine residue 27 of the metabotropic glutamate receptor 2 (Grm2), but exposure to a $2 \mathrm{~h}$ restraint stress transiently normalized this effect. $24 \mathrm{~h}$ later, acetylation levels of Grm2 returned to below baseline, indicating that multiple stressors can temporarily change the epigenetic landscape of neuronal cells. Stress-induced epigenetic changes such as this likely induce a transcriptional profile that contributes to the behavioral response to stress, including activities such as coping or the expression of anxiety and generalized fear.

Systemic administration of the HDAC inhibitors sodium butyrate (NaB) (Yamawaki et al. 2012; Han et al. 2014;
Valvassori et al. 2014, 2015), trichostatin A (Miyagawa et al. 2012), and valproic acid (Wilson et al. 2014), which elevate histone acetylation levels, has therapeutic effects in rodent stress paradigms, improving cognition, and reducing anxiety behaviors. Predator stress elevates expression of histone deacetylases themselves (Wilson et al. 2014; Ragu Varman and Rajan 2015) and knockdown of the Hdac6 isoform reduces anxiety (Fukada et al. 2012), suggesting that restoring acetylation levels to baseline may improve stress-related behavioral responses. Indeed, treatment with $\mathrm{NaB}$ in a model of chronic restraint stress was sufficient to reduce depression and anxiety behaviors, accompanied by restoration of HDAC2 and histone H3 acetylation levels (Han et al. 2014). Likewise, in an acute restraint stress paradigm, pretreatment with trichostatin A prevented stress-induced novelty suppression and increased acetylation of histones $\mathrm{H} 3$ and $\mathrm{H} 4$ (Miyagawa et al. 2012).

Strikingly, the bulk of epigenetic stress research has focused on expression changes of epigenetic machinery in the cortex and hippocampus. Undoubtedly, these two regions are critically involved in stress responses, but given that the amygdala contributes heavily to the expression of anxiety and is centrally involved in the modulation of emotional fear memories (discussed below), functional characterization of amygdala-driven epigenetic marks would be expected to provide important insight into stress pathologies.

\section{The neuroepigenetics of fear memory}

The epigenetics of fear memory have been covered in a number of reviews (Roth et al. 2010; Zovkic et al. 2013; Kwapis and Wood 2014; Rudenko and Tsai 2014), so we will provide just a brief summary here for the purposes of discussion. In the most basic terms, the hippocampus is crucial for contextual fear conditioning and the amygdala for cued fear conditioning. Accordingly, DNA methyltransferase (DNMT) inhibition in Area CA1 following training disrupts consolidation of contextual fear and DNMT inhibition in the lateral amygdala disrupts consolidation of cued fear (Miller and Sweatt 2007; Miller et al. 2008; Monsey et al. 2011). Bidirectional changes in the methylation status of several memory-related genes, including $P p 1 c b$, reelin, and $B d n f$, have also been found in the hippocampus following fear learning (Miller and Sweatt 2007; Lubin et al. 2008). Consistent with these findings, mice fed a diet deficient in the methyl donors folate, methionine, and choline from 3 to $6 \mathrm{wk}$ of age to drive a global reduction in DNA methylation levels, have impaired fear memory formation that persists into adulthood (Ishii et al. 2014). Finally, cortical DNA methylation supports the storage of remote (30-d-old) fear memory (Miller et al. 2010), suggesting that targeting this epigenetic mechanism may be useful in treating the pathological persistence of fear memories in PTSD.

Histone acetylation has been found to promote fear learning (Korzus et al. 2004; Wood et al. 2005). Systemic administration of $\mathrm{NaB}$ prior to contextual fear conditioning strengthened long-term retention of the fear memory, without altering the short-term memory (Levenson et al. 2004). Although this study found acetylation of histone $\mathrm{H} 3$ in the hippocampus to be important, other studies have also demonstrated involvement of acetylated histones H4 and H2B (Peleg et al. 2010; Bousiges et al. 2013). Gupta et al. found that $\mathrm{NaB}$ can support consolidation of contextual fear memory by increasing methylation at a histone lysine residue associated with active transcription, $\mathrm{H} 3 \mathrm{~K} 4 \mathrm{me} 3$, at the Zif268 promoter in the hippocampus (Gupta et al. 2010). In addition, Monsey et al. found that infusion of an HDAC inhibitor into the lateral amygdala increases H3 acetylation and enhances the consolidation of cued fear conditioning (Monsey et al. 2011). 
Other studies have shown that histone modifications that increase transcription of $B d n f$ and Homer1a in the hippocampus and amygdala promote fear learning (Lubin et al. 2008; Takei et al. 2011; Mahan et al. 2012).

More recently, the study of chromatin in memory formation has gone beyond specific histone lysine modifications to chromatin remodeling, a process in which ATP-dependent nucleosome complexes disrupt the contacts with DNA (Vogel-Ciernia et al. 2013). Similar to the effects of histone modifications, this influences transcription by regulating physical access to regions of DNA. Vogel-Ciernia and colleagues demonstrated that mice haploinsufficient for BAF53b, a neuron-specific chromatin regulatory subunit, had synaptic plasticity and long-term, but not shortterm, memory deficits. Importantly, rescuing BAF53b in the adult hippocampus was sufficient to restore memory (Vogel-Ciernia et al. 2013). Furthermore, inhibiting nuclear protein phosphatase 1 in the amygdala can control chromatin remodeling, producing histone modifications and changes in gene expression that correlate with enhanced fear memory (Koshibu et al. 2011).

\section{Epigenetics and the modulation of fear memory}

A core feature of PTSD is the presence of a traumatic memory that is long-lasting and persists, despite repeatedly encountering triggers without the traumatic event reoccurring (extinction). Given that the majority of patients are diagnosed with PTSD long after consolidation of the traumatic experience, a practical approach to treatment is to modulate, or even disrupt the existing, pathogenic memories of the event. This can be done through extinction or a blockade of reconsolidation, a brief period of lability following retrieval during which the memory is susceptible to disruption. In the clinic, extinction has been targeted in the form of prolonged exposure (PE) and is commonly used by Veterans Affairs (Kudler et al. 2016). In PE, patients are re-exposed to their trauma through several different methods (e.g., imagery, virtual reality, and discussion of the trauma) as a means of reducing emotional reactivity to the trauma. However, although considered a first-line approach by many clinicians, the results have been mixed; PE improves PTSD symptoms in only a portion of patients and exacerbates them in others (Steenkamp 2016a,b; Yehuda and Hoge 2016). Although PE has not proven to be particularly successful, identifying the mechanisms responsible for successful extinction, including epigenetics, could, theoretically, lead to improved outcomes through pharmacologically enhanced or accelerated extinction.

Because the infralimbic region of the PFC (IL) is crucial for extinction learning (Peters et al. 2010; Sierra-Mercado et al. 2011), the majority of studies investigating the role of DNA methylation in fear extinction have focused here. Gene-specific changes in DNA methylation appear to support extinction learning. Some studies report that demethylation in the IL is associated with extinction learning (Rudenko et al. 2013; Li et al. 2014), whereas others have found an increase in methyl-CpG binding protein (Mecp2), a protein known to promote gene silencing through binding to methylated DNA, with extinction (Wei et al. 2012). $B d n f$ is a critical factor in extinction learning (Peters et al. 2010). Interestingly, female mice are more resistant to fear extinction than male mice and exhibit increased cytosine methylation of $B d n f$ exon IV and decreased exon IV mRNA expression within the mPFC (Baker-Andresen et al. 2013).

Histone acetylation also participates in extinction learning. Systemic administration of HDAC inhibitors facilitates extinction of cued and contextual fear memories (Li et al. 2006; Bredy et al. 2007; Lattal et al. 2007; Bredy and Barad 2008; Stafford et al. 2012). Because HDAC inhibitors can also promote fear learning (Levenson et al. 2004; Bredy and Barad 2008; Guan et al. 2009;
Gupta et al. 2010), the timing of treatment with an HDAC inhibitor is important, particularly if given systemically, in that its administration must be tightly coupled with extinction training under optimal parameters (e.g., duration of exposure to the CS) to ensure strengthening of the extinction memory and not the original fear memory.

Epigenetic studies of the IL have found that a decrease in HDAC2 levels accompanies extinction (Wei et al. 2012), and $\mathrm{NaB}$ induces IL acetylation and an increase in the immediate early gene Fos (Stafford et al. 2012). In addition, histone H4 acetylation at $B d n f$ 's exon IV gene promoter and corresponding increases in mRNA in the IL appear to be particularly important for extinction learning (Bredy et al. 2007). Levels of p300/CREB binding protein (CBP)-associated factor (PCAF), a histone acetyltransferase (HAT), also increase in the IL with extinction learning and this HAT has been shown to selectively target extinction processes over acquisition. Interestingly, evidence indicates that PCAF functions as a transcriptional coactivator to repress Zif268, thereby promoting fear extinction and limiting fear reconsolidation, the restabilization of a fear memory following its reactivation (Wei et al. 2012).

Although the studies above demonstrate that general increases in acetylation support extinction, extinction is also associated with gene-specific decreases in acetylation. For example, extinction decreases $\mathrm{H} 3$ acetylation around the promoter region of the Bdnf exon 1 gene in the PFC (Bredy et al. 2007), suggesting that exon-specific regulation of $B d n f$ may be important. Additionally, levels of the HAT p300/CBP decrease with extinction and its inhibition enhances extinction consolidation and LTP in the IL (Marek et al. 2011). Finally, mice overexpressing Hdac1 in the dorsal hippocampus display enhanced extinction of contextual fear memory, whereas HDAC1 inhibition results in a blockade of extinction. In this study, Hdac1 overexpression resulted in decreased H3K9 acetylation and increased H3K9 trimethylation at the Fos promoter in the hippocampus, with a concomitant decrease in Fos mRNA (Bahari-Javan et al. 2012). This case highlights the different effects that may result from inhibition of a single HDAC, rather than multiple isoforms with existing pharmacological HDAC inhibitors.

Extinction can inhibit fear expression, but return of the fear memory is always a possibility through spontaneous renewal (Bouton 2002). This is particularly relevant because PE therapy is context specific, such that the fear memory can return when the context is changed. In consideration of these features, extinction alone may be unable to produce the longlasting effects required to permanently abolish the influence of traumatic memories. Indeed, some have suggested the persistence of traumatic memories in PTSD arises from frequent reexperiencing of the trauma, creating an "overconsolidated" memory trace. Thus, another approach being considered is direct disruption of memory trace by preventing reconsolidation following retrieval.

It is widely accepted that a memory is formed in a stabilized, time-dependent manner, thereby rendering the memory resistant to loss (McGaugh 2000; Alberini 2005). Importantly, while being stabilized, these memories can be strengthened or updated (Lee 2008; Forcato et al. 2011; Gräff et al. 2014). Reconsolidation is thought to be a way for the brain to incorporate new information into existing memory traces (Alberini and Ledoux 2013). Following a reactivation trial, consolidated memories become labile and sensitive to disruption by protein synthesis inhibitors, behavior modification, brain lesions, and a variety of smallmolecule inhibitors (Nader et al. 2000; Miller and Sweatt 2006; Bredy and Barad 2008; Monfils et al. 2009; Maddox and Schafe 2011). Many have successfully used pharmacological agents such as the FDA-approved $\beta$-adrenergic antagonist, propranolol, in preclinical studies to prevent reconsolidation of fear memories 
as a means of memory "erasure" (Debiec and Ledoux 2004). However, translating these achievements to the clinic has come with varying levels of success (Soeter and Kindt 2012; Steenen et al. 2016). This has motivated investigations of additional mechanisms, including epigenetic modifications.

Although additional work is needed, DNA methylation has emerged as one possible negative regulator of reconsolidation. Maddox and colleagues demonstrated that the DNMT inhibitors, 5-aza-2'-deoxycytidine and RG108, impaired reconsolidation when infused into the lateral amygdala after reactivation (Maddox et al. 2014). This corresponded with a reduction in neural plasticity in the lateral amygdala.

Similar to initial consolidation, increased acetylation appears to enhance reconsolidation. In work by Lubin and Sweatt, the nuclear factor kappa-light-chain-enhancer of activated B cells (NF-кB) signaling pathway was found to participate in reconsolidation in a manner independent of NF- $\kappa B^{\prime}$ s role as a transcription factor. Reactivation of a fear memory induced phosphorylation and acetylation of histone $\mathrm{H} 3$ at the promoter of the immediate early gene, Zif268, which was attenuated when rats were treated with the IKK $\alpha$ inhibitor, diethyldithiocarbamate (DDTC). Because IKK $\alpha$ interacts with CBP, an HAT, the authors postulated that IKK $\alpha$ mediates its chromatin modulating effects by inducing histone acetylation via enhanced CBP activity (Lubin and Sweatt 2007). Intra-lateral amygdala infusions of the p300/CBP inhibitor, C646, also impair reconsolidation when administered shortly after fear memory retrieval (Maddox et al. 2013b). This was not limited to newly consolidated memories, as 2 -wk-old memories were also sensitive to disruption by C646. Furthermore, memories disrupted by C646 did not display spontaneous recovery, reinstatement, or renewal (Maddox et al. 2014), strengthening the argument for disruption of the original memory trace, rather than an extinction-related effect. Consistent with this, a similar reconsolidation deficit has been reported with garcinol, a compound with several pharmacological actions, including HAT inhibition (Maddox et al. 2013a).

Although epigenetic manipulations of reconsolidation appears to be an attractive avenue for targeting traumatic memories in stress-induced disorders such as PTSD (Kwapis and Wood 2014), the boundary conditions of reconsolidation (e.g., age of memory, length of activation trial, and time of post-activation intervention) should be kept in mind. For instance, older (remote) memories are less likely to undergo reconsolidation after memory reactivation (Milekic and Alberini 2002; Gräff et al. 2014). Further, although extinction and reconsolidation are distinct processes (Suzuki et al. 2004; Miller and Sweatt 2006), the duration of reactivation (where the US is not present) plays a significant role in determining which process is recruited (Pedreira and Maldonado 2003; Suzuki et al. 2004), with shorter durations skewing toward reconsolidation. Finally, reconsolidation occurs within a finite temporal window, ranging from $10 \mathrm{~min}$ to $6 \mathrm{~h}$ postreactivation, depending on the exact mechanism (Monfils et al. 2009). This restricts the use of pharmaceuticals to ones that reach peak bioavailability inside the window appropriate for the given mechanism of action.

Recent work has shown that strategies combining elements of extinction and reconsolidation may have synergistic effects, while overcoming some of their individual obstacles. Gräff and colleagues found that HDAC2-specific inhibition with CI-994 induced hippocampus-dependent plasticity, which is required to update a fear memory trace during extinction, even when the memory was weeks old (Gräff et al. 2014). This suggests that HDAC inhibitors may have the potential to induce plasticity in deeply engrained traumatic memories, enabling their disruption through appropriately timed behavioral therapy.

\section{The neuroepigenetics of stress-enhanced fear learning}

Several recent reviews have covered the broad array of neurobiological players that have been found to mediate SEFL, such as glucocorticoids, glutamate, glycine, and cytokines (Cordero et al. 2003; Akirav and Maroun 2007; Iwamoto et al. 2007; Kohda et al. 2007; Yamamoto et al. 2009; Tronson et al. 2010; Jones et al. 2015; Maren and Holmes 2016; Perusini et al. 2016). However, in spite of the contribution of epigenetic mechanisms to stress and numerous aspects of fear memory independently, very little work has been done in the realm of epigenetics at the crossroads between stress and fear memory. Epigenetic-driven synergy between stress and fear could occur through a variety of routes, which are not mutually exclusive. Epigenetic mechanisms are particularly intriguing candidates to explore in SEFL because even transient modifications can produce persistent gene and protein expression changes (Weaver et al. 2004; Kumar et al. 2005). Further, DNA methylation and some chromatin modifications associated with both stress and fear memory can, themselves, persist for very long periods of time (Miller et al. 2010; Stankiewicz et al. 2013; Halder et al. 2016). The brain may be made more vulnerable to "overconsolidation" of a pathological memory by a stressful experience through transient or persistent, gene-specific epigenetic changes triggered by the stressor in brain regions affected by both stress and fearful associations, such as the amygdala (e.g., epigenetic repression of memory suppressors, such as PP1 and calcineurin; Miller and Sweatt 2007; Baumgartel et al. 2008; Herzog et al. 2008; Miller et al. 2010). This same stressor could raise the transcriptional threshold of genes utilized by the brain's extinction circuit, such that pro-extinction genes are epigenetically repressed through DNA methylation and histone methylation at inhibitory lysine residues.

Another area of SEFL and PTSD that has rich potential for epigenetic involvement is susceptibility versus resilience in the face of trauma. Despite the majority of the population experiencing at least one traumatic event in their lifetime, the lifetime prevalence of PTSD is only $\sim 7 \%$ (Kessler et al. 2005). This suggests that there may be protective factors, both environmental and molecular, that lend resilience to some when exposed to a traumatic event, whereas other factors confer vulnerability to develop PTSD. For example, early-life adversity, such as maternal stress, loss of or separation from a parent, and chronic environmental stress, is a significant environmental risk factor for the development of PTSD (Koenen et al. 2007). A number of human and animal studies have established a clear, potentially causal, epigenetic link between early-life stress and altered stress responses later in life (Daskalakis et al. 2013; Vaiserman 2015; Yehuda et al. 2015b). Some SEFL protocols use an early-life stressor, such as maternal separation, rather than an acute stressor in adulthood, and find that it prevents the infantile amnesia that typically occurs when fear conditioning is performed in early life (Callaghan et al. 2013; Quinn et al. 2014). Unfortunately, the effects of early-life stress on fear conditioning performed in adulthood are mixed, with some reporting an enhancement (Toda et al. 2014) and others an impairment (Stevenson et al. 2009). Additional work is needed to clarify the parameters of an SEFL model that reflects the effect of early-life adversity on later trauma. However, once established, studying the underlying epigenetic mechanisms will be extremely important (Toda et al. 2014). Another SEFL approach has been to use Long Evans rats, an outbred strain, to identify the individual rats that are susceptible or resilient to the effects of stress in adulthood on fear conditioning (Rau et al. 2005). An advance here would involve identification of a susceptible and resilient population in response to SEFL within an inbred strain, as it would provide a powerful tool for interrogating the underlying epigenetic contributions by removing genetic vulnerability factors. 
Although researchers are just beginning to identify the neuroepigenetic players involved in SEFL, a few studies have been published (Table 2). For instance, SPS before fear conditioning results in a delayed extinction profile (Yamamoto et al. 2009; Chauveau et al. 2012; Sawamura et al. 2016), an effect that can be rescued by treatment with an HDAC inhibitor (Matsumoto et al. 2013). This is not surprising, given that HDAC inhibitors increase acetylation to support extinction learning and decrease anxiety in animal stress paradigms (Yamawaki et al. 2012; Valvassori et al. 2014). The perseverant nature of these stress-enhanced traumatic memories may be due to a very strong epigenetic-regulated learning experience, as this model can also result in "overconsolidation" and enhanced acetylation of the Bdnf promoter by histones H3 and H4 (Takei et al. 2011).

Only two studies, to date, have examined DNA methylation in SEFL, focusing on Ntsr1 and Fkbp5. Ntsr1 encodes the receptor for neurotensin 1, an endogenous neuropeptide implicated in anxiety and densely expressed in the amygdala. The authors report that an SEFL model involving maternal separation was associated with decreased Ntsr1 mRNA and increased methylation of its promoter (Toda et al. 2014). Fkbp5 is a crucial regulator of glucocorticoid receptor (GR) and in turn, the sensitivity of the hypothalamic pituitary axis that mediates stress responses. A reduction in FKBP5 levels have been reported in PTSD patients (Yehuda et al. 2009), and changes in methylation of the FKBP5 gene have been found in holocaust survivors and their offspring (Yehuda et al. 2015a). Pretreatment with the synthetic corticosteroid dexamethasone prior to extinction not only rescued stress-induced fear extinction deficits but also regulated the expression of Fkbp 5 mRNA and expression of the DNA methylation regulators Dnmt $3 a$ and $3 b$ and Tet1, 2, and 3 (Sawamura et al. 2016). The correlative data from this study demonstrate a pattern of $F k b p 5$ methylation linked to an accelerated extinction profile in an SEFL model, strengthening the notion that DNA methylation of key genes involved in both stress and memory may impact the degree of stress-enhanced fear learning, extinction, and retention.

\section{Implications for PTSD}

The contribution of neuroepigenetics to PTSD is essentially untapped in the human brain, because of several limitations. Such studies are beginning to take into account the relevance of epigenetic modifications to disease state and therapeutic potential (Norrholm et al. 2013; Labonte et al. 2014; Malan-Muller et al. 2014; Rampp et al. 2014; Yehuda et al. 2015b), but the majority are limited to measurements from peripheral fluids (e.g., blood, plasma, and saliva). The stability and longevity of epigenetic mechanisms allows for correlations to stress history in a retrospective fashion and associations with other epidemiological data, such as disease risk, drug history, and genetic background. However, methylation status and histone modifications in peripheral blood and saliva have not yet been shown to accurately represent neuroepigenetic states in PTSD subjects, especially considering subregion-specific modifications in the brain. Measurement of epigenetic marks in post-mortem PTSD brains will be necessary to reconcile these issues and provide additional insight regarding the contribution of epigenetics to disease duration and outcome.

Another significant challenge to patient studies is controlling for the wide range of stressors that individual study participants incur throughout the course of their lifetime, which can alter a person's response to a traumatic event, as well as the brain's molecular landscape, particularly in terms of persistent epigenomic changes. Further, a number of neuropsychiatric disorders, such as major depressive disorder and substance use disorder, have a strong co-morbidity with PTSD and are accompanied by an element of stress associated with the chronicity of the disease (e.g., major depressive disorder, substance abuse disorder). Thus, the interpretation of such human studies is limited and often cannot be purely dissociated from other psychiatric illnesses. This latter point reiterates the strong need to understand the epigenetic effects of stress on the brain's memory systems because, ultimately, these changes may push an individual into a more severe disease state, such as PTSD.

Although the field's understanding of neuroepigenetic contributions to PTSD from patient studies is extremely limited, findings from animal models hint at the importance of these molecular processes and should eventually be translated to human studies to further characterize potential targets in the treatment of PTSD. One such area that can be addressed relates to gender-specific mechanisms of PTSD pathology. In humans, females are twice as likely to develop PTSD, yet the majority of animal studies have been performed in males. Therefore, SEFL paradigms performed in both genders simultaneously are expected to provide insight into the elevated vulnerability of females to develop PTSD. For example, female mice subjected to subchronic variable stress are susceptible to a depression phenotype, whereas males are resilient (Hodes et al. 2015). This gender discrepancy was linked to the expression levels of the DNA methyltransferase Dnmt3a, which is elevated in the nucleus accumbens in females, but not males, after stress. In terms of sex differences in fear memory, the results are mixed and difficult to extrapolate to the human condition of PTSD. For instance, male rats freeze more than female rats in memory retention tests of cued fear conditioning (Maren et al. 1994), and female rats extinguish faster than their male counterparts (Dalla and Shors 2009; Glover et al. 2015). This picture is complicated by recent work showing that female mice cope differently in behavioral assays such as fear conditioning, which may confound interpretation of their behavioral output (Jones and Monfils 2016). Despite this, there is evidence that the sexual bias seen in PTSD may have epigenetic underpinnings. For example, the neuropeptide, PACAP, a regulator of the

Table 2. Known neuroepigenetic mechanisms of SEFL

\begin{tabular}{|c|c|c|c|c|c|}
\hline Species & Stressor & Finding & Epigenetic mark & Brain region & Citation \\
\hline Rats & Maternal separation & $\begin{array}{l}\text { Increased methylation of the } \\
\text { neurotensin receptor }\end{array}$ & DNA methylation of Ntsr1 & Amygdala & Toda et al. (2014) \\
\hline Rats & $\begin{array}{l}\text { Single-prolonged } \\
\text { stress (SPS) }\end{array}$ & $\begin{array}{l}\text { HDAC inhibitor vorinostat facilitates } \\
\text { contextual fear extinction }\end{array}$ & $\begin{array}{l}\text { General histone } \mathrm{H} 3 \\
\text { acetylation }\end{array}$ & Hippocampus & Matsumoto et al. (2013) \\
\hline Rats & $\begin{array}{l}\text { Single-prolonged } \\
\text { stress (SPS) }\end{array}$ & $\begin{array}{l}\text { SEFL induces epigenetic regulation of } \\
\text { BDNF }\end{array}$ & $\begin{array}{l}\text { Histones } \mathrm{H} 3 / \mathrm{H} 4 \text { are } \\
\text { hyperacetylated at BDNF } \\
\text { promoters }\end{array}$ & Hippocampus & Takei et al. (2011) \\
\hline Mice & $\begin{array}{l}\text { Restraint/ } \\
\text { immobilization }\end{array}$ & $\begin{array}{l}\text { Dexamethasone alters } \mathrm{Dnmt} / \mathrm{Tet} \\
\text { genes and Fkbp5 methylation } \\
\text { status in SEFL }\end{array}$ & $\begin{array}{l}\text { DNA methylation of intron } 5 \\
\text { CpG } 4 / 5 \text { of Fkbp5 }\end{array}$ & Amygdala & Sawamura et al. (2016) \\
\hline
\end{tabular}


brain's stress response, has been associated with PTSD in human patients. Not only is PACAP differentially regulated in women exposed to trauma, its expression is increased in the amygdala and mPFC following cued fear conditioning. Interestingly, hypermethylation of the gene responsible for encoding PACAP's receptor, PAC1, is predictive of PTSD in a sex-specific manner (Ressler et al. 2011). This work highlights the importance of studying sexual dimorphism in PTSD, as sex-specific epigenetic differences may provide an important avenue for identifying susceptibility mechanisms that can be targeted for therapies.

ALthough the existing literature on the epigenetics of SEFL is limited, data on the epigenetics of stress and fear conditioning separately are likely to shed light on the epigenetics of SEFL. For example, epigenetic modifications of the exon IV region of $B d n f$ are linked to both stress and learning and memory events (Bredy et al. 2007; Lubin et al. 2008; Roth et al. 2011), suggesting that epigenetic modification of $B d n f$ will likely modulate behavior in an SEFL model as well. Support for BDNF participating in emotional learning has been recently translated from animal studies to PTSD in humans. Individuals with the BDNF polymorphism Val66Met have impaired fear memory extinction (Soliman et al. 2010). The extensive work on $B d n f$ in animal models has been influential in establishing a role for epigenetic mechanisms in PTSD and $B d n f$ is, by far, the most neuroepigenetically studied gene in emotional behaviors. Most likely, it represents a broad spectrum of neuroepigenetic molecular targets waiting to be identified in PTSD.

However, it is important to go beyond the current animal literature on stress and fear conditioning separately and further examine neuroepigenetics in the context of the SEFL models discussed in this review. Figure 1 depicts the different ways in which stress can influence subsequent fear learning in SEFL models. Stress results in epigenetic modifications, and it is likely that the nature and location of the stress-induced epigenetic change dictates the subsequent effect on memory. Deciphering epigenetic mechanisms mediating SEFL is likely to reveal unique molecular players and brain regions that participate specifically in the interaction between stress and fear memory and reveal new therapeutic targets for the treatment of PTSD.

\section{Acknowledgments}

This work was funded by The National Institute of Mental Health under grant no. R01MH105400 (C.A.M.), the National Institute on Drug Abuse under grant nos. K99DA041469 (S.E.S.) and K01DA040737 (A.M.B.), and the Brain and Behavior Foundation (A.M.B. and S.E.S.).

\section{References}

Akirav I, Maroun M. 2007. The role of the medial prefrontal cortex-amygdala circuit in stress effects on the extinction of fear. Neural Plast 2007: 30873 .

Akirav I, Segev A, Motanis H, Maroun M. 2009. D-cycloserine into the BLA reverses the impairing effects of exposure to stress on the extinction of contextual fear, but not conditioned taste aversion. Learn Memory 16: $682-686$.

Alberini CM. 2005. Mechanisms of memory stabilization: are consolidation and reconsolidation similar or distinct processes? Trends Neurosci 28: $51-56$.

Alberini CM, Ledoux JE. 2013. Memory reconsolidation. Curr Biol 23: R746-R750.

Albucher RC, Liberzon I. 2002. Psychopharmacological treatment in PTSD: a critical review. J Psychiatr Res 36: 355-367.

Andero R, Brothers SP, Jovanovic T, Chen YT, Salah-Uddin H, Cameron M, Bannister TD, Almli L, Stevens JS, Bradley B, et al. 2013. Amygdala-dependent fear is regulated by Oprl1 in mice and humans with PTSD. Sci Transl Med 5: 188ra173.

Andero R, Heldt SA, Ye K, Liu X, Armario A, Ressler KJ. 2011. Effect of 7,8-dihydroxyflavone, a small-molecule TrkB agonist, on emotional learning. Am J Psychiatry 168: 163-172.
Bahari-Javan S, Maddalena A, Kerimoglu C, Wittnam J, Held T, Bahr M, Burkhardt S, Delalle I, Kugler S, Fischer A, et al. 2012. HDAC1 regulates fear extinction in mice. J Neurosci 32: 5062-5073.

Baker-Andresen D, Flavell CR, Li X, Bredy TW. 2013. Activation of BDNF signaling prevents the return of fear in female mice. Learn Memory 20: 237-240.

Baratta MV, Kodandaramaiah SB, Monahan PE, Yao J, Weber MD, Lin PA, Gisabella B, Petrossian N, Amat J, Kim K, et al. 2015. Stress enables reinforcement-elicited serotonergic consolidation of fear memory. Biol Psychiatry 79: 814-822.

Baumgartel K, Genoux D, Welzl H, Tweedie-Cullen RY, Koshibu K, Livingstone-Zatchej M, Mamie C, Mansuy IM. 2008. Control of the establishment of aversive memory by calcineurin and Zif268. Nat Neurosci 11: 572-578.

Bilang-Bleuel A, Ulbricht S, Chandramohan Y, De Carli S, Droste SK, Reul JM. 2005. Psychological stress increases histone H3 phosphorylation in adult dentate gyrus granule neurons: involvement in a glucocorticoid receptor-dependent behavioural response. Eur J Neurosci 22: 1691-1700.

Blechert J, Michael T, Vriends N, Margraf J, Wilhelm FH. 2007. Fear conditioning in posttraumatic stress disorder: evidence for delayed extinction of autonomic, experiential, and behavioural responses. Behav Res Ther 45: 2019-2033.

Bousiges O, Neidl R, Majchrzak M, Muller MA, Barbelivien A, Pereira de Vasconcelos A, Schneider A, Loeffler JP, Cassel JC, Boutillier AL. 2013. Detection of histone acetylation levels in the dorsal hippocampus reveals early tagging on specific residues of $\mathrm{H} 2 \mathrm{~B}$ and $\mathrm{H} 4$ histones in response to learning. PLoS One 8: e57816.

Bouton ME. 2002. Context, ambiguity, and unlearning: sources of relapse after behavioral extinction. Biol Psychiatry 52: 976-986.

Bowen MT, Dass SA, Booth J, Suraev A, Vyas A, McGregor IS. 2014. Active coping toward predatory stress is associated with lower corticosterone and progesterone plasma levels and decreased methylation in the medial amygdala vasopressin system. Horm Behav 66: 561-566.

Bramham CR, Panja D. 2014. BDNF regulation of synaptic structure, function, and plasticity. Neuropharmacology 76(Pt C): 601-602.

Bredy TW, Barad M. 2008. The histone deacetylase inhibitor valproic acid enhances acquisition, extinction, and reconsolidation of conditioned fear. Learn Mem 15: 39-45.

Bredy TW, Wu H, Crego C, Zellhoefer J, Sun YE, Barad M. 2007. Histone modifications around individual BDNF gene promoters in prefrontal cortex are associated with extinction of conditioned fear. Learn Mem 14: $268-276$.

Brennan FX, Beck KD, Ross RJ, Servatius RJ. 2005. Stress-induced increases in avoidance responding: an animal model of post-traumatic stress disorder behavior? Neuropsychiatr Dis Treat 1: 69-72.

Brennan FX, Beck KD, Servatius RJ. 2006. Predator odor exposure facilitates acquisition of a leverpress avoidance response in rats. Neuropsychiatr Dis Treat 2: 65-69.

Breslau N, Koenen KC, Luo Z, Agnew-Blais J, Swanson S, Houts RM, Poulton R, Moffitt TE. 2014. Childhood maltreatment, juvenile disorders and adult post-traumatic stress disorder: a prospective investigation. Psychol Med 44: 1937-1945.

Callaghan BL, Graham BM, Li S, Richardson R. 2013. From resilience to vulnerability: mechanistic insights into the effects of stress on transitions in critical period plasticity. Front Psychiatry 4: 90.

Chauveau F, Lange MD, Jungling K, Lesting J, Seidenbecher T, Pape HC. 2012. Prevention of stress-impaired fear extinction through neuropeptide s action in the lateral amygdala. Neuropsychopharmacology 37: $1588-1599$.

Chertkow-Deutsher Y, Cohen H, Klein E, Ben-Shachar D. 2010. DNA methylation in vulnerability to post-traumatic stress in rats: evidence for the role of the post-synaptic density protein Dlgap2. Int $J$ Neuropsychopharmacol 13: 347-359.

Cordero MI, Venero C, Kruyt ND, Sandi C. 2003. Prior exposure to a single stress session facilitates subsequent contextual fear conditioning in rats. Evidence for a role of corticosterone. Horm Behav 44: 338-345.

Dalla C, Shors TJ. 2009. Sex differences in learning processes of classical and operant conditioning. Physiol Behav 97: 229-238.

Daskalakis NP, Bagot RC, Parker KJ, Vinkers CH, de Kloet ER. 2013. The three-hit concept of vulnerability and resilience: toward understanding adaptation to early-life adversity outcome. Psychoneuroendocrinology 38: $1858-1873$.

Debiec J, Ledoux JE. 2004. Disruption of reconsolidation but not consolidation of auditory fear conditioning by noradrenergic blockade in the amygdala. Neuroscience 129: 267-272.

de Kleine RA, Smits JA, Hendriks GJ, Becker ES, van Minnen A. 2015. Extinction learning as a moderator of d-cycloserine efficacy for enhancing exposure therapy in posttraumatic stress disorder. J Anxiety Disord 34: 63-67.

Dell'Osso L, Carmassi C, Del Debbio A, Catena Dell'Osso M, Bianchi C, da Pozzo E, Origlia N, Domenici L, Massimetti G, Marazziti D, et al. 2009. 
Brain-derived neurotrophic factor plasma levels in patients suffering from post-traumatic stress disorder. Prog Neuropsychopharmacol Biol Psychiatry 33: 899-902.

Dubreucq S, Matias I, Cardinal P, Haring M, Lutz B, Marsicano G, Chaouloff F. 2012. Genetic dissection of the role of cannabinoid type-1 receptors in the emotional consequences of repeated social stress in mice. Neuropsychopharmacology 37: 1885-1900.

Forcato C, Rodriguez ML, Pedreira ME. 2011. Repeated labilization-reconsolidation processes strengthen declarative memory in humans. PLoS One 6: e23305.

Fuchikami M, Yamamoto S, Morinobu S, Takei S, Yamawaki S. 2010. Epigenetic regulation of BDNF gene in response to stress. Psychiatry Investig 7: 251-256.

Fukada M, Hanai A, Nakayama A, Suzuki T, Miyata N, Rodriguiz RM, Wetsel WC, Yao TP, Kawaguchi Y. 2012. Loss of deacetylation activity of Hdac6 affects emotional behavior in mice. PLoS One 7: e30924.

Furukawa-Hibi Y, Nagai T, Yun J, Yamada K. 2015. Stress increases DNA methylation of the neuronal PAS domain 4 (Npas4) gene. Neuroreport 26: $827-832$.

Garfinkel SN, Abelson JL, King AP, Sripada RK, Wang X, Gaines LM, Liberzon I. 2014. Impaired contextual modulation of memories in PTSD: an fMRI and psychophysiological study of extinction retention and fear renewal. J Neurosci 34: 13435-13443.

Glover EM, Jovanovic T, Norrholm SD. 2015. Estrogen and extinction of fear memories: implications for posttraumatic stress disorder treatment. Biol Psychiatry 78: 178-185.

Gräff J, Joseph NF, Horn ME, Samiei A, Meng J, Seo J, Rei D, Bero AW, Phan TX, Wagner F, et al. 2014. Epigenetic priming of memory updating during reconsolidation to attenuate remote fear memories. Cell 156: 261-276.

Grillon C. 2002. Startle reactivity and anxiety disorders: aversive conditioning, context, and neurobiology. Biol Psychiatry 52: 958-975.

Guan JS, Haggarty SJ, Giacometti E, Dannenberg JH, Joseph N, Gao J, Nieland TJ, Zhou Y, Wang X, Mazitschek R, et al. 2009. HDAC2 negatively regulates memory formation and synaptic plasticity. Nature 459: $55-60$.

Gudsnuk K, Champagne FA. 2012. Epigenetic influence of stress and the social environment. ILAR J 53: 279-288.

Guo JU, Su Y, Zhong C, Ming GL, Song H. 2011. Hydroxylation of 5 -methylcytosine by TET1 promotes active DNA demethylation in the adult brain. Cell 145: 423-434.

Gupta S, Kim SY, Artis S, Molfese DL, Schumacher A, Sweatt JD, Paylor RE, Lubin FD. 2010. Histone methylation regulates memory formation. J Neurosci 30: 3589-3599.

Halder R, Hennion M, Vidal RO, Shomroni O, Rahman RU, Rajput A, Centeno TP, van Bebber F, Capece V, Garcia Vizcaino JC, et al. 2016. DNA methylation changes in plasticity genes accompany the formation and maintenance of memory. Nat Neurosci 19: 102-110.

Han A, Sung YB, Chung SY, Kwon MS. 2014. Possible additional antidepressant-like mechanism of sodium butyrate: targeting the hippocampus. Neuropharmacology 81: 292-302.

Hauck S, Kapczinski F, Roesler R, de Moura Silveira E Jr, Magalhaes PV, Kruel LR, Schestatsky SS, Ceitlin LH. 2010. Serum brain-derived neurotrophic factor in patients with trauma psychopathology. Prog Neuropsychopharmacol Biol Psychiatry 34: 459-462.

Herzog CJ, Miot S, Mansuy IM, Giros B, Tzavara ET. 2008. Chronic valproate normalizes behavior in mice overexpressing calcineurin. Eur $J$ Pharmacol 580: 153-160.

Hodes GE, Pfau ML, Purushothaman I, Ahn HF, Golden SA, Christoffel DJ, Magida J, Brancato A, Takahashi A, Flanigan ME, et al. 2015. Sex differences in nucleus accumbens transcriptome profiles associated with susceptibility versus resilience to subchronic variable stress. $J$ Neurosci 35: 16362-16376.

Hunter RG, McCarthy KJ, Milne TA, Pfaff DW, McEwen BS. 2009. Regulation of hippocampal H3 histone methylation by acute and chronic stress. Proc Natl Acad Sci 106: 20912-20917.

Ieraci A, Mallei A, Musazzi L, Popoli M. 2015. Physical exercise and acute restraint stress differentially modulate hippocampal brain-derived neurotrophic factor transcripts and epigenetic mechanisms in mice. Hippocampus 25: 1380-1392.

Ishii D, Matsuzawa D, Matsuda S, Tomizawa H, Sutoh C, Shimizu E. 2014. Methyl donor-deficient diet during development can affect fear and anxiety in adulthood in C57BL/6J mice. PLoS One 9: e105750.

Iwamoto Y, Morinobu S, Takahashi T, Yamawaki S. 2007. Single prolonged stress increases contextual freezing and the expression of glycine transporter 1 and vesicle-associated membrane protein 2 mRNA in the hippocampus of rats. Prog Neuropsychopharmacol Biol Psychiatry 31: 642-651.

Izquierdo A, Wellman CL, Holmes A. 2006. Brief uncontrollable stress causes dendritic retraction in infralimbic cortex and resistance to fear extinction in mice. J Neurosci 26: $5733-5738$.
Jones CE, Monfils M-H. 2016. Fight, flight, or freeze? The answer may depend on your sex. Trends Neurosci 39: 51-53.

Jones ME, Lebonville CL, Barrus D, Lysle DT. 2015. The role of brain interleukin-1 in stress-enhanced fear learning. Neuropsychopharmacology 40: 1289-1296.

Kaas GA, Zhong C, Eason DE, Ross DL, Vachhani RV, Ming GL, King JR, Song H, Sweatt JD. 2013. TET1 controls CNS 5-methylcytosine hydroxylation, active DNA demethylation, gene transcription, and memory formation. Neuron 79: 1086-1093.

Karpova NN. 2014. Role of BDNF epigenetics in activity-dependent neuronal plasticity. Neuropharmacology 76(Pt C): 709-718.

Kessler RC, Chiu WT, Demler O, Merikangas KR, Walters EE. 2005. Prevalence, severity, and comorbidity of 12-month DSM-IV disorders in the National Comorbidity Survey Replication. Arch Gen Psychiatry 62: $617-627$.

Khan S, Liberzon I. 2004. Topiramate attenuates exaggerated acoustic startle in an animal model of PTSD. Psychopharmacology (Berl) 172: 225-229.

Kim JK, Samaranayake M, Pradhan S. 2009. Epigenetic mechanisms in mammals. Cell Mol Life Sci 66: 596-612.

Knox D, Nault T, Henderson C, Liberzon I. 2012. Glucocorticoid receptors and extinction retention deficits in the single prolonged stress model. Neuroscience 223: 163-173.

Koenen KC, Moffitt TE, Poulton R, Martin J, Caspi A. 2007. Early childhood factors associated with the development of post-traumatic stress disorder: results from a longitudinal birth cohort. Psychol Med 37: 181-192.

Kohda K, Harada K, Kato K, Hoshino A, Motohashi J, Yamaji T, Morinobu S, Matsuoka N, Kato N. 2007. Glucocorticoid receptor activation is involved in producing abnormal phenotypes of single-prolonged stress rats: a putative post-traumatic stress disorder model. Neuroscience 148: $22-33$.

Korzus E, Rosenfeld MG, Mayford M. 2004. CBP histone acetyltransferase activity is a critical component of memory consolidation. Neuron 42: 961-972.

Koshibu K, Gräff J, Mansuy IM. 2011. Nuclear protein phosphatase-1: an epigenetic regulator of fear memory and amygdala long-term potentiation. Neuroscience 173: 30-36.

Kriaucionis S, Heintz N. 2009. The nuclear DNA base 5-hydroxymethylcytosine is present in Purkinje neurons and the brain. Science 324: 929-930.

Kudler H, Day K, Schnurr PP. 2016. Treatment options for veterans with posttraumatic stress disorder. JAMA Psychiatry 73: 756-757.

Kumar A, Choi KH, Renthal W, Tsankova NM, Theobald DE, Truong HT, Russo SJ, Laplant Q, Sasaki TS, Whistler KN, et al. 2005. Chromatin remodeling is a key mechanism underlying cocaine-induced plasticity in striatum. Neuron 48: 303-314.

Kwapis JL, Wood MA. 2014. Epigenetic mechanisms in fear conditioning: implications for treating post-traumatic stress disorder. Trends Neurosci 37: 706-720

Labonte B, Azoulay N, Yerko V, Turecki G, Brunet A. 2014. Epigenetic modulation of glucocorticoid receptors in posttraumatic stress disorder. Transl Psychiatry 4: e368.

Lattal KM, Barrett RM, Wood MA. 2007. Systemic or intrahippocampal delivery of histone deacetylase inhibitors facilitates fear extinction. Behav Neurosci 121: 1125-1131.

Lee JL. 2008. Memory reconsolidation mediates the strengthening of memories by additional learning. Nat Neurosci 11: 1264-1266.

Levenson JM, O'Riordan KJ, Brown KD, Trinh MA, Molfese DL, Sweatt JD. 2004. Regulation of histone acetylation during memory formation in the hippocampus. J Biol Chem 279: 40545-40559.

Li S, Murakami Y, Wang M, Maeda K, Matsumoto K. 2006. The effects of chronic valproate and diazepam in a mouse model of posttraumatic stress disorder. Pharmacol Biochem Behav 85: 324-331.

Li X, Wei W, Ratnu VS, Bredy TW. 2013. On the potential role of active DNA demethylation in establishing epigenetic states associated with neural plasticity and memory. Neurobiol Learn Mem 105: 125-132.

Li X, Wei W, Zhao QY, Widagdo J, Baker-Andresen D, Flavell CR, D'Alessio A, Zhang Y, Bredy TW. 2014. Neocortical Tet3-mediated accumulation of 5-hydroxymethylcytosine promotes rapid behavioral adaptation. Proc Natl Acad Sci 111: 7120-7125.

Li S, Papale LA, Kintner DB, Sabat G, Barrett-Wilt GA, Cengiz P, Alisch RS 2015. Hippocampal increase of 5-hmC in the glucocorticoid receptor gene following acute stress. Behav Brain Res 286: 236-240.

Li S, Papale LA, Zhang Q, Madrid A, Chen L, Chopra P, Keles S, Jin P, Alisch RS. 2016. Genome-wide alterations in hippocampal 5-hydroxymethylcytosine links plasticity genes to acute stress. Neurobiol Dis 86: 99-108.

Liberzon I, Krstov M, Young EA. 1997. Stress-restress: effects on ACTH and fast feedback. Psychoneuroendocrinology 22: 443-453.

Lu B, Nagappan G, Lu Y. 2014. BDNF and synaptic plasticity, cognitive function, and dysfunction. Handb Exp Pharmacol 220: 223-250. 
Lubin FD, Sweatt JD. 2007. The IкB kinase regulates chromatin structure during reconsolidation of conditioned fear memories. Neuron 55: 942-957.

Lubin FD, Roth TL, Sweatt JD. 2008. Epigenetic regulation of BDNF gene transcription in the consolidation of fear memory. J Neurosci 28: 10576-10586.

Maddox SA, Schafe GE. 2011. Epigenetic alterations in the lateral amygdala are required for reconsolidation of a Pavlovian fear memory. Learn Mem 18: $579-593$.

Maddox SA, Watts CS, Doyere V, Schafe GE. 2013a. A naturally-occurring histone acetyltransferase inhibitor derived from Garcinia indica impairs newly acquired and reactivated fear memories. PLoS One 8: e54463.

Maddox SA, Watts CS, Schafe GE. 2013b. p300/CBP histone acetyltransferase activity is required for newly acquired and reactivated fear memories in the lateral amygdala. Learn Memory 20: 109-119.

Maddox SA, Watts CS, Schafe GE. 2014. DNA methyltransferase activity is required for memory-related neural plasticity in the lateral amygdala. Neurobiol Learn Mem 107: 93-100.

Mahan AL, Mou L, Shah N, Hu JH, Worley PF, Ressler KJ. 2012. Epigenetic modulation of Homer1a transcription regulation in amygdala and hippocampus with pavlovian fear conditioning. J Neurosci 32: $4651-4659$.

Malan-Muller S, Seedat S, Hemmings SM. 2014. Understanding posttraumatic stress disorder: insights from the methylome. Genes Brain Behav 13: 52-68.

Marek R, Coelho CM, Sullivan RK, Baker-Andresen D, Li X, Ratnu V, Dudley KJ, Meyers D, Mukherjee C, Cole PA, et al. 2011. Paradoxical enhancement of fear extinction memory and synaptic plasticity by inhibition of the histone acetyltransferase p300. J Neurosci 31: $7486-7491$.

Maren S, Holmes A. 2016. Stress and fear extinction. Neuropsychopharmacology 41: $58-79$.

Maren S, De Oca B, Fanselow MS. 1994. Sex differences in hippocampal long-term potentiation (LTP) and Pavlovian fear conditioning in rats: positive correlation between LTP and contextual learning. Brain Res 661: $25-34$

Maroun M, Ioannides PJ, Bergman KL, Kavushansky A, Holmes A, Wellman CL. 2013. Fear extinction deficits following acute stress associate with increased spine density and dendritic retraction in basolateral amygdala neurons. Eur J Neurosci 38: 2611-2620.

Matsumoto Y, Morinobu S, Yamamoto S, Matsumoto T, Takei S, Fujita Y, Yamawaki S. 2013. Vorinostat ameliorates impaired fear extinction possibly via the hippocampal NMDA-CaMKII pathway in an animal model of posttraumatic stress disorder. Psychopharmacology (Berl) 229: $51-62$.

McGaugh JL. 2000. Memory-a century of consolidation. Science 287: $248-251$.

Meyer RM, Burgos-Robles A, Liu E, Correia SS, Goosens KA. 2014. A ghrelin-growth hormone axis drives stress-induced vulnerability to enhanced fear. Mol Psychiatry 19: 1284-1294.

Meyer-Lindenberg A, Domes G, Kirsch P, Heinrichs M. 2011. Oxytocin and vasopressin in the human brain: social neuropeptides for translational medicine. Nat Rev Neurosci 12: 524-538.

Milad MR, Pitman RK, Ellis CB, Gold AL, Shin LM, Lasko NB, Zeidan MA, Handwerger K, Orr SP, Rauch SL. 2009. Neurobiological basis of failure to recall extinction memory in posttraumatic stress disorder. Biol Psychiatry 66: $1075-1082$.

Milekic MH, Alberini CM. 2002. Temporally graded requirement for protein synthesis following memory reactivation. Neuron 36: 521-525.

Miller CA, Sweatt JD. 2006. Amnesia or retrieval deficit? Implications of a molecular approach to the question of reconsolidation. Learn Memory 13: $498-505$

Miller CA, Sweatt JD. 2007. Covalent modification of DNA regulates memory formation. Neuron 53: 857-869.

Miller CA, Campbell SL, Sweatt JD. 2008. DNA methylation and histone acetylation work in concert to regulate memory formation and synaptic plasticity. Neurobiol Learn Mem 89: 599-603.

Miller CA, Gavin CF, White JA, Parrish RR, Honasoge A, Yancey CR, Rivera IM, Rubio MD, Rumbaugh G, Sweatt JD. 2010. Cortical DNA methylation maintains remote memory. Nat Neurosci 13: 664-666.

Miracle AD, Brace MF, Huyck KD, Singler SA, Wellman CL. 2006. Chronic stress impairs recall of extinction of conditioned fear. Neurobiol Learn Mem 85: 213-218.

Miyagawa K, Tsuji M, Takeda H. 2012. [Possible involvement of histone acetylation in the development of emotional resistance to stress stimuli]. Nihon Shinkei Seishin Yakurigaku Zasshi 32: 263-267.

Monfils MH, Cowansage KK, Klann E, LeDoux JE. 2009. Extinction-reconsolidation boundaries: key to persistent attenuation of fear memories. Science 324: 951-955.

Monsey MS, Ota KT, Akingbade IF, Hong ES, Schafe GE. 2011. Epigenetic alterations are critical for fear memory consolidation and synaptic plasticity in the lateral amygdala. PLoS One 6: e19958.
Nader K, Schafe GE, Le Doux JE. 2000. Fear memories require protein synthesis in the amygdala for reconsolidation after retrieval. Nature 406: $722-726$.

Nasca C, Zelli D, Bigio B, Piccinin S, Scaccianoce S, Nistico R, McEwen BS. 2015. Stress dynamically regulates behavior and glutamatergic gene expression in hippocampus by opening a window of epigenetic plasticity. Proc Natl Acad Sci 112: 14960-14965.

Norrholm SD, Jovanovic T, Olin IW, Sands LA, Karapanou I, Bradley B, Ressler KJ. 2011. Fear extinction in traumatized civilians with posttraumatic stress disorder: relation to symptom severity. Biol Psychiatry 69: 556-563.

Norrholm SD, Jovanovic T, Smith AK, Binder E, Klengel T, Conneely K, Mercer KB, Davis JS, Kerley K, Winkler J, et al. 2013. Differential genetic and epigenetic regulation of catechol-O-methyltransferase is associated with impaired fear inhibition in posttraumatic stress disorder. Front Behav Neurosci 7: 30 .

Pedreira ME, Maldonado H. 2003. Protein synthesis subserves reconsolidation or extinction depending on reminder duration. Neuron 38: $863-869$.

Peleg S, Sananbenesi F, Zovoilis A, Burkhardt S, Bahari-Javan S, Agis-Balboa RC, Cota P, Wittnam JL, Gogol-Doering A, Opitz L, et al. 2010. Altered histone acetylation is associated with age-dependent memory impairment in mice. Science 328: 753-756.

Perusini JN, Meyer EM, Long VA, Rau V, Nocera N, Avershal J, Maksymetz J, Spigelman I, Fanselow MS. 2016. Induction and expression of fear sensitization caused by acute traumatic stress. Neuropsychopharmacology 41: $45-57$.

Peters J, Dieppa-Perea LM, Melendez LM, Quirk GJ. 2010. Induction of fear extinction with hippocampal-infralimbic BDNF. Science 328: $1288-1290$.

Pitman RK, Rasmusson AM, Koenen KC, Shin LM, Orr SP, Gilbertson MW, Milad MR, Liberzon I. 2012. Biological studies of post-traumatic stress disorder. Nat Rev Neurosci 13: 769-787.

Quinn JJ, Skipper RA, Claflin DI. 2014. Infant stress exposure produces persistent enhancement of fear learning across development. Dev Psychobiol 56: 1008-1016.

Ragu Varman D, Rajan KE. 2015. Environmental enrichment reduces anxiety by differentially activating serotonergic and neuropeptide $\mathrm{Y}$ (NPY)-ergic system in indian field mouse (Mus booduga): an animal model of post-traumatic stress disorder. PLoS One 10: e0127945.

Rampp C, Binder EB, Provencal N. 2014. Epigenetics in posttraumatic stress disorder. Prog Mol Biol Transl Sci 128: 29-50.

Rau V, DeCola JP, Fanselow MS. 2005. Stress-induced enhancement of fear learning: an animal model of posttraumatic stress disorder. Neurosci Biobehav Rev 29: 1207-1223.

Ressler KJ, Mercer KB, Bradley B, Jovanovic T, Mahan A, Kerley K, Norrholm SD, Kilaru V, Smith AK, Myers AJ, et al. 2011. Post-traumatic stress disorder is associated with PACAP and the PAC1 receptor. Nature 470: $492-497$.

Rodrigues GM Jr, Toffoli LV, Manfredo MH, Francis-Oliveira J, Silva AS, Raquel HA, Martins-Pinge MC, Moreira EG, Fernandes KB, Pelosi GG, et al. 2015. Acute stress affects the global DNA methylation profile in rat brain: modulation by physical exercise. Behav Brain Res 279: 123-128.

Rodriguez Manzanares PA, Isoardi NA, Carrer HF, Molina VA. 2005. Previous stress facilitates fear memory, attenuates GABAergic inhibition, and increases synaptic plasticity in the rat basolateral amygdala. J Neurosci 25: $8725-8734$.

Rosas-Vidal LE, Do-Monte FH, Sotres-Bayon F, Quirk GJ. 2014. Hippocampal - prefrontal BDNF and memory for fear extinction. Neuropsychopharmacology 39: 2161-2169.

Roth TL, Roth ED, Sweatt JD. 2010. Epigenetic regulation of genes in learning and memory. Essays Biochem 48: 263-274.

Roth TL, Zoladz PR, Sweatt JD, Diamond DM. 2011. Epigenetic modification of hippocampal Bdnf DNA in adult rats in an animal model of post-traumatic stress disorder. J Psychiatr Res 45: 919-926.

Rotllant D, Pastor-Ciurana J, Armario A. 2013. Stress-induced brain histone H3 phosphorylation: contribution of the intensity of stressors and length of exposure. J Neurochem 125: 599-609.

Rougemont-Bucking A, Linnman C, Zeffiro TA, Zeidan MA, Lebron-Milad K, Rodriguez-Romaguera J, Rauch SL, Pitman RK, Milad MR. 2011. Altered processing of contextual information during fear extinction in PTSD: an fMRI study. CNS Neurosci Ther 17: 227-236.

Rudenko A, Tsai LH. 2014. Epigenetic regulation in memory and cognitive disorders. Neuroscience 264: 51-63.

Rudenko A, Dawlaty MM, Seo J, Cheng AW, Meng J, Le T, Faull KF, Jaenisch R, Tsai LH. 2013. Tet1 is critical for neuronal activity-regulated gene expression and memory extinction. Neuron 79: 1109-1122.

Sawamura T, Klengel T, Armario A, Jovanovic T, Norrholm SD, Ressler KJ, Andero R. 2016. Dexamethasone treatment leads to enhanced fear extinction and dynamic Fkbp5 regulation in amygdala. Neuropsychopharmacology 41: 832-846. 
Shors TJ, Weiss C, Thompson RF. 1992. Stress-induced facilitation of classical conditioning. Science 257: 537-539.

Sierra-Mercado D, Padilla-Coreano N, Quirk GJ. 2011. Dissociable roles of prelimbic and infralimbic cortices, ventral hippocampus, and basolateral amygdala in the expression and extinction of conditioned fear. Neuropsychopharmacology 36: 529-538.

Soeter M, Kindt M. 2012. Stimulation of the noradrenergic system during memory formation impairs extinction learning but not the disruption of reconsolidation. Neuropsychopharmacology 37: 1204-1215.

Soliman F, Glatt CE, Bath KG, Levita L, Jones RM, Pattwell SS, Jing D, Tottenham N, Amso D, Somerville LH, et al. 2010. A genetic variant BDNF polymorphism alters extinction learning in both mouse and human. Science 327: 863-866.

Stafford JM, Raybuck JD, Ryabinin AE, Lattal KM. 2012. Increasing histone acetylation in the hippocampus-infralimbic network enhances fear extinction. Biol Psychiatry 72: 25-33.

Stankiewicz AM, Swiergiel AH, Lisowski P. 2013. Epigenetics of stress adaptations in the brain. Brain Res Bull 98: 76-92.

Steenen SA, van Wijk AJ, van der Heijden GJ, van Westrhenen R, de Lange J, de Jongh A. 2016. Propranolol for the treatment of anxiety disorders: Systematic review and meta-analysis. J Psychopharmacol 30: 128-139.

Steenkamp MM. 2016a. Treatment options for veterans with posttraumatic stress disorder-reply. JAMA Psychiatry 73: 757-758.

Steenkamp MM. 2016b. True evidence-based care for posttraumatic stress disorder in military personnel and veterans. JAMA Psychiatry 73: 431-432.

Stevens JS, Almli LM, Fani N, Gutman DA, Bradley B, Norrholm SD, Reiser E, Ely TD, Dhanani R, Glover EM, et al. 2014. PACAP receptor gene polymorphism impacts fear responses in the amygdala and hippocampus. Proc Natl Acad Sci 111: 3158-3163.

Stevenson CW, Meredith JP, Spicer CH, Mason R, Marsden CA. 2009. Early life programming of innate fear and fear learning in adult female rats. Behav Brain Res 198: $51-57$.

Suvrathan A, Bennur S, Ghosh S, Tomar A, Anilkumar S, Chattarji S. 2014. Stress enhances fear by forming new synapses with greater capacity for long-term potentiation in the amygdala. Philos Trans R Soc Lond B Biol Sci 369: 20130151

Suzuki A, Josselyn SA, Frankland PW, Masushige S, Silva AJ, Kida S. 2004. Memory reconsolidation and extinction have distinct temporal and biochemical signatures. J Neurosci 24: 4787-4795.

Szczytkowski-Thomson JL, Lebonville CL, Lysle DT. 2013. Morphine prevents the development of stress-enhanced fear learning. Pharmacol Biochem Behav 103: 672-677.

Takahashi T, Morinobu S, Iwamoto Y, Yamawaki S. 2006. Effect of paroxetine on enhanced contextual fear induced by single prolonged stress in rats. Psychopharmacology (Berl) 189: 165-173.

Takei S, Morinobu S, Yamamoto S, Fuchikami M, Matsumoto T, Yamawaki S. 2011. Enhanced hippocampal BDNF/TrkB signaling in response to fear conditioning in an animal model of posttraumatic stress disorder. J Psychiatr Res 45: 460-468.

Toda H, Boku S, Nakagawa S, Inoue T, Kato A, Takamura N, Song N, Nibuya M, Koyama T, Kusumi I. 2014. Maternal separation enhances conditioned fear and decreases the mRNA levels of the neurotensin receptor 1 gene with hypermethylation of this gene in the rat amygdala. PLoS One 9: e97421.

Tronson NC, Guzman YF, Guedea AL, Huh KH, Gao C, Schwarz MK, Radulovic J. 2010. Metabotropic glutamate receptor 5/Homer interactions underlie stress effects on fear. Biol Psychiatry 68: 1007-1015.

Vaiserman AM. 2015. Epigenetic programming by early-life stress: evidence from human populations. Dev Dyn 244: 254-265.

Vaissiere T, Sawan C, Herceg Z. 2008. Epigenetic interplay between histone modifications and DNA methylation in gene silencing. Mutat Res 659: $40-48$.

Valvassori SS, Varela RB, Arent CO, Dal-Pont GC, Bobsin TS, Budni J, Reus GZ, Quevedo J. 2014. Sodium butyrate functions as an antidepressant and improves cognition with enhanced neurotrophic expression in models of maternal deprivation and chronic mild stress. Curr Neurovasc Res 11: 359-366.

Valvassori SS, Resende WR, Budni J, Dal-Pont GC, Bavaresco DV, Reus GZ, Carvalho AF, Goncalves CL, Furlanetto CB, Streck EL, et al. 2015. Sodium butyrate, a histone deacetylase inhibitor, reverses behavioral and mitochondrial alterations in animal models of depression induced by early- or late-life stress. Curr Neurovasc Res 12: 312-320.

Vialou V, Feng J, Robison AJ, Nestler EJ. 2013. Epigenetic mechanisms of depression and antidepressant action. Annu Rev Pharmacol Toxicol 53: $59-87$.

Vogel-Ciernia A, Matheos DP, Barrett RM, Kramar EA, Azzawi S, Chen Y, Magnan CN, Zeller M, Sylvain A, Haettig J, et al. 2013. The neuron-specific chromatin regulatory subunit BAF53b is necessary for synaptic plasticity and memory. Nat Neurosci 16: $552-561$.

Weaver IC, Cervoni N, Champagne FA, D'Alessio AC, Sharma S, Seckl JR, Dymov S, Szyf M, Meaney MJ. 2004. Epigenetic programming by maternal behavior. Nat Neurosci 7: 847-854.

Wei W, Coelho CM, Li X, Marek R, Yan S, Anderson S, Meyers D, Mukherjee C, Sbardella G, Castellano S, et al. 2012. p300/ CBP-associated factor selectively regulates the extinction of conditioned fear. J Neurosci 32: 11930-11941.

Wilson CB, McLaughlin LD, Ebenezer PJ, Nair AR, Francis J. 2014. Valproic acid effects in the hippocampus and prefrontal cortex in an animal model of post-traumatic stress disorder. Behav Brain Res 268: 72-80.

Wood MA, Kaplan MP, Park A, Blanchard EJ, Oliveira AM, Lombardi TL, Abel T. 2005. Transgenic mice expressing a truncated form of CREB-binding protein (CBP) exhibit deficits in hippocampal synaptic plasticity and memory storage. Learn Mem 12: 111-119.

Yamamoto S, Morinobu S, Fuchikami M, Kurata A, Kozuru T, Yamawaki S. 2008. Effects of single prolonged stress and D-cycloserine on contextual fear extinction and hippocampal NMDA receptor expression in a rat model of PTSD. Neuropsychopharmacology 33: 2108-2116.

Yamamoto S, Morinobu S, Takei S, Fuchikami M, Matsuki A, Yamawaki S, Liberzon I. 2009. Single prolonged stress: toward an animal model of posttraumatic stress disorder. Depress Anxiety 26: 1110-1117.

Yamawaki Y, Fuchikami M, Morinobu S, Segawa M, Matsumoto T, Yamawaki S. 2012. Antidepressant-like effect of sodium butyrate (HDAC inhibitor) and its molecular mechanism of action in the rat hippocampus. World J Biol Psychiatry 13: 458-467.

Yehuda R, Hoge CW. 2016. Treatment options for veterans with posttraumatic stress disorder-reply. JAMA Psychiatry 73: 758.

Yehuda R, Cai G, Golier JA, Sarapas C, Galea S, Ising M, Rein T, Schmeidler J, Muller-Myhsok B, Holsboer F, et al. 2009. Gene expression patterns associated with posttraumatic stress disorder following exposure to the World Trade Center attacks. Biol Psychiatry 66: 708-711.

Yehuda R, Daskalakis NP, Bierer LM, Bader HN, Klengel T, Holsboer F, Binder EB. 2015a. Holocaust exposure induced intergenerational effects on FKBP5 methylation. Biol Psychiatry, in press. doi: 10.1016/ j.biopsych.2015.08.005.

Yehuda R, Flory JD, Bierer LM, Henn-Haase C, Lehrner A, Desarnaud F, Makotkine I, Daskalakis NP, Marmar CR, Meaney MJ. 2015b. Lower methylation of glucocorticoid receptor gene promoter $1 \mathrm{~F}$ in peripheral blood of veterans with posttraumatic stress disorder. Biol Psychiatry 77: 356-364.

Zhou VW, Goren A, Bernstein BE. 2011. Charting histone modifications and the functional organization of mammalian genomes. Nat Rev Genet 12: $7-18$.

Zovkic IB, Guzman-Karlsson MC, Sweatt JD. 2013. Epigenetic regulation of memory formation and maintenance. Learn Mem 20: 61-74.

Received March 15, 2016; accepted in revised form July 14, 2016. 


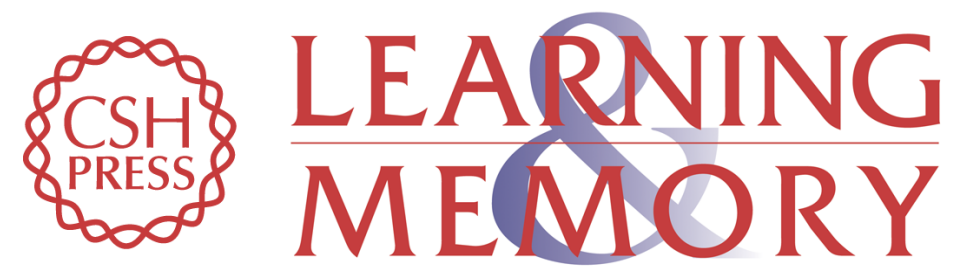

\section{The potential of epigenetics in stress-enhanced fear learning models of PTSD}

Ashley M. Blouin, Stephanie E. Sillivan, Nadine F. Joseph, et al.

Learn. Mem. 2016, 23:

Access the most recent version at doi:10.1101/Im.040485.115

References This article cites 168 articles, 33 of which can be accessed free at: http://learnmem.cshlp.org/content/23/10/576.full.html\#ref-list-1

Creative This article is distributed exclusively by Cold Spring Harbor Laboratory Press for the Commons License first 12 months after the full-issue publication date (see

http://learnmem.cshlp.org/site/misc/terms.xhtml). After 12 months, it is available under a Creative Commons License (Attribution-NonCommercial 4.0 International), as described at http://creativecommons.org/licenses/by-nc/4.0/.

Email Alerting Receive free email alerts when new articles cite this article - sign up in the box at the Service top right corner of the article or click here. 